\title{
Dexamethasone Therapy in Preterm Infants Developing Bronchopulmonary Dysplasia: Effect on Pulmonary Surfactant Disaturated-Phosphatidylcholine Kinetics
}

\author{
PAOLA E. COGO, MANUELA SIMONATO, GIANNA MARIATOFFOLO, GIORGIO STEFANUTTI, MARCO CHIERICI, \\ CLAUDIO COBELLI, CARLO ORI, AND VIRGILIO P. CARNIELLI
}

\begin{abstract}
Departments of Pediatrics [P.E.C., M.S.], Pediatric Surgery [G.S.], Information Engineering [G.M.T., M.C., C.C.] and Pharmacology and Anaesthesia [C.O.], University of Padova, 35128 Padova, Italy; Neonatal Division [V.P.C.], Salesi Children Hospital, University of Ancona, 62100 Ancona, Italy; Institute of Child Health-Great Ormond Street Hospital and Neonatal Unit-University College Hospitals
\end{abstract} [V.P.C.], W1N1DD London, United Kingdom

\begin{abstract}
The role of corticosteroid in severe bronchopulmonary dyplasia (BPD) is still debated. Scanty data are available on the corticosteroids effect on surfactant metabolism. Our objective was to compare surfactant kinetics in preterm infants with developing BPD, before and after dexamethasone (DEXA) treatment. Twenty-eight studies were performed in 14 preterm infants (birth weight $786 \pm$ $192 \mathrm{~g}$, gestational age $26 \pm 1 \mathrm{wk}$ ) on high ventilatory setting, before (age $22 \pm 11 \mathrm{~d}$ ) and after (age $33 \pm 11 \mathrm{~d}$ ) DEXA. ${ }^{13} \mathrm{C}$-labeled dipalmitoyl-phosphatidylcholine (DPPC) was administered endotrachelly to trace pulmonary surfactant. Surfactant disaturatedphosphatidylcholine (DSPC) kinetics and pools were calculated from DSPC ${ }^{13} \mathrm{C}$-enrichment curves of serial tracheal aspirates and bicompartmental analysis. Total protein and myeloperoxidase (MPO) activity in tracheal aspirates were also measured and expressed per $\mathrm{ml}$ of Epithelial Lining Fluid (ELF). After DEXA, DSPC alveolar pool increased significantly from $8.2 \pm 7.6$ to $10.6 \pm 11.3 \mathrm{mg} / \mathrm{kg}$ $(p=0.039)$, total proteins and MPO were reduced from $8.8 \pm 8.6$ to $3.1 \pm 2.1 \mathrm{mg} / \mathrm{ml} \mathrm{ELF}(p=0.046)$ and from $1822 \pm 1224$ to $1261 \pm$ $987 \mathrm{mU} / \mathrm{mlELF}(p=0.028)$ respectively. In conclusion, DEXA treatment in mechanically ventilated preterm infants with severe respiratory failure and at high risk of developing BPD, significantly reduced inflammatory markers and increased alveolar surfactant DSPC pool. (Pediatr Res 63: 433-437, 2008)
\end{abstract}

$\mathrm{B}$ ronchopulmonary dysplasia (BPD) remains the most common respiratory complication of very preterm infants. Its pathogenesis recognizes multiple factors, such as prenatal infection, lung immaturity, volutrauma and barotrauma, oxygen toxicity, lung edema and airway inflammation, which probably act additively or synergistically to promote lung injury. Primary or secondary inflammatory reaction leads to an amplification of lung insult, interferes with alveolarization and alters lung development $(1,2)$. Reduced surfactant synthesis and/or surfactant inhibition/inactivation due to lung immaturity and to protein leak across the alveolar capillary barrier have been described in association with marked alterations of surfactant phospholipids (3-5). More recently, Ballard et al. demonstrated a reduction in surfactant specific

Received August 22, 2007; accepted November 12, 2007.

Correspondence: Paola E. Cogo, M.D., Ph.D., Department of Pediatrics, University of Padova, Via Giustiniani 3 - 35128 Padova, Italy; e-mail: cogo@pediatria.unipd.it

Supported by the Laboratory of Nutrition and Metabolism of the Department of Pediatrics, University of Padova, Italy. proteins in tracheal aspirates of preterm infants with developing BPD (6).

The association between lung inflammation and BPD constitutes the rationale for the use of corticosteroids as antiinflammatory drugs. Corticosteroids are potent antiinflammatory agents; they reduce polymorphonuclear cells recruitment in the lungs, inhibit the production of elastase, prostaglandins, leucotrienes, tumor necrosis factor, and interleukins, decrease vascular permeability and pulmonary edema, and increase synthesis of anti-oxidant enzymes (7). Despite the recent findings of a strong negative effect on neurodevelopment, corticosteroids are still being used for life-threatening ventilator dependent respiratory failure (810). In premature rabbits, dexamethasone (DEXA) decreases protein leak across the endothelium but not across the epithelium (11). In preterm infants with developing BPD, DEXA decreases the albumin concentration in tracheal aspirates (12), and reduces the influx of inflammatory cells, the release of cytokines $(13,14)$, plasma sE-sL selectins, and soluble adhesion molecules $(15,16)$.

The effect of corticosteroids on surfactant system has been assessed in animals, where they induce both transcriptional and posttranscriptional up-regulation of a number of surfactant associated genes, including those controlling the expression of the surfactant proteins and fatty acid synthase (17). In preterm newborns with BPD, Kari et al. showed that DEXA significantly decreased the nonsedimentable protein in epithelial lining fluid, whereas it did not affect the concentration of surfactant phosphatidycholine, 1L-1 B and lactoferrin (18). No data are available on the effect of corticosteroids on surfactant kinetics in human BPD.

We have recently described a method for the measurement of surfactant kinetics in humans. The method consists in the endotracheal administration of a tracer dose of ${ }^{13} \mathrm{C}$ labeled dipalmitoyl-phosphatidylcholine (DPPC) and subsequent measurements the ${ }^{13} \mathrm{C}$-enrichment of surfactant disaturated-

Abbreviations: BPD, bronchopulmonary dysplasia; DPPC, dipalmitoylphosphatidylcholine; DSPC, disaturated-phosphatidylcholine; DEXA, dexamethasone; ELF, epithelial lining fluid; $\mathbf{F i O}{ }_{2}$, fraction of inspired oxygen; MAP, mean airway pressure; MPO, Myeloperoxidase 
phosphatidylcholine (DSPC) from serial tracheal aspirates (19). Based on the assumptions that the tracer is distributed between the alveolar and lung tissue pools, a bicompartmental analysis of the tracer to tracee ratio allows the estimation of the alveolar and lung tissue DSPC pools and of DSPC synthesis and fluxes between the two pools (20).

In this study, we compared the effect of a 10-day tapering dose of DEXA on surfactant DSPC kinetics in preterm infants with developing BPD.

\section{MATERIALS AND METHODS}

Patients. Patients were admitted to the Neonatal Intensive Care, Department of Pediatrics, University of Padua, Italy, from 1999 to 2002. The study was approved by the local Research and Ethic Committee. We enrolled 17 preterm infants at very high risk of developing severe BPD and thus of being treated with DEXA. Newborns were considered eligible for the study if they 1) were on ventilator support with a fraction of inspired oxygen $\left(\mathrm{FiO}_{2}\right)>0.55$ and worsening respiratory failure, 2) had a chest x-ray suggestive of BPD, and 3 ) had no biochemical and microbiological signs of infection. Six ventilator dependant preterm infants, with a postnatal age comparable with that of the preterm infants after "DEXA treatment," were used as controls.

Study design. The study compared surfactant DSPC kinetics before and after DEXA. Total proteins content and myeloperoxidase (MPO) activity were also measured from the tracheal aspirates.

After parental consent, infants with severe ventilator dependent respiratory failure deemed likely to be treated with DEXA at about $3 \mathrm{wk}$ of age received $2.5 \mathrm{mg} / \mathrm{kg}$ of [U- $\left.{ }^{13} \mathrm{C}-\mathrm{PA}\right]-\mathrm{DPPC}(1 \mathrm{mg} / \mathrm{mL}$ of normal saline) to trace endogenous surfactant DSPC. A second endotracheal dose of $2.5 \mathrm{mg} / \mathrm{kg}$ of $\left[\mathrm{U}^{-13} \mathrm{C}-\right.$ PA]-DPPC was administered $2 \mathrm{~d}$ after starting DEXA. Clinical data are reported in Table 1. Tracheal aspirates were collected during each study before the administration of the tracer $(t=0)$, every $6 \mathrm{~h}$ for the first $72 \mathrm{~h}$, and then every $12 \mathrm{~h}$ for another $4 \mathrm{~d}$ or until extubation. Tracheal aspirates were performed as previously described $(19,21)$. Briefly, after instillation of $0.5 \mathrm{~mL}$ of $0.9 \%$ saline in the endotracheal tube, the neonate was gently hand-bagged and then tracheal secretions were collected through a Lukens trap. They were kept at $+4^{\circ} \mathrm{C}$ for no longer than $3 \mathrm{~h}$ and brought to a final volume of $2 \mathrm{~mL}$ with $0.9 \%$ saline. After gentle vortex for $1-\mathrm{min}, 300 \mu \mathrm{L}$ of tracheal aspirate fluid were freeze-thawed 3 times in liquid nitrogen and centrifuged at 13,000 $\mathrm{rpm}(2325 \mathrm{~g})$ for $45-\mathrm{min}$ at $4^{\circ} \mathrm{C}$. The supernatant was collected and stored at $-20^{\circ} \mathrm{C}$ for MPO determination. The remaining tracheal aspirate volume was centrifuged at $400 \mathrm{~g}$ for $10-\mathrm{min}$. The supernatant was recovered and kept at $-20^{\circ} \mathrm{C}$ until analysis.

Ventilatory parameters were recorded before the start of the study and subsequently every $12 \mathrm{~h}$.

The decisions of starting DEXA and the timing of extubation were taken by the attending physician, who was not involved in the study. DEXA was started at an initial dose of $0.5 \mathrm{mg} / \mathrm{kg} / \mathrm{d}$ for $3 \mathrm{~d}$ followed by a tapering scheme to complete the course in about $10 \mathrm{~d}$.

Protein content. Protein content in tracheal aspirates was assayed according to Lowrie (22), by using autoanalyser Cobas Mira (Roche) with "Pyrogallol cod.CC02120" (Analitica triveneta s.r.l) and BSA as standard at 100 $\mathrm{mg} / \mathrm{mL}$. The coefficient of variation of the assay was $3.8 \%$. Results were expressed in $\mathrm{mg} / \mathrm{mL}$ epithelial lining fluid (ELF) after correction with the urea method (23).

MPO activity. Pulmonary neutrophils sequestration was quantified by measurement of MPO activity (24). One hundred microliters of supernatant was added to $2.9 \mathrm{~mL}$ of a $50 \mathrm{mM}$ phosphate buffer $(\mathrm{pH}$ 6.0) containing 0.53

Table 1. Clinical characteristics of the 13 study infants before and after DEXA treatment

\begin{tabular}{lccc}
\hline & $\begin{array}{c}\text { Before DEXA } \\
(n=13)\end{array}$ & $\begin{array}{c}\text { After DEXA } \\
(n=13)\end{array}$ & $\begin{array}{c}p \text { before/after } \\
\text { DEXA }\end{array}$ \\
\hline Body weight $(\mathrm{g})$ & $817 \pm 174$ & $889 \pm 198$ & 0.03 \\
Postnatal age $(\mathrm{d})$ & $22.1 \pm 11.3$ & $33.1 \pm 11.4$ & $<0.01$ \\
${\text { Mean } \mathrm{FiO}_{2} \text { (fraction) }}_{\text {Mean airway pressure }}$ & $0.70 \pm 0.13$ & $0.58 \pm 0.23$ & 0.15 \\
$\quad\left(\mathrm{~cm} \mathrm{H}_{2} \mathrm{O}\right)$ & & $7.2 \pm 3.8$ & $<0.01$ \\
\hline
\end{tabular}

Data are expressed as mean $\pm \mathrm{SD}$.

DEXA, dexamethasone.
mM O-dianisidine hydrochloride (Sigma Chemical Co. Chemical) and $0.0005 \%$ hydrogen peroxide (Carlo Erba, Milan, Italy). MPO activity was followed spectrophotometrically at $25^{\circ} \mathrm{C}$ at a wavelength of $460 \mathrm{~nm}$ for $3 \mathrm{~min}$. MPO activity was corrected by the urea dilution method and expressed as units (U) per milliliter of ELF (24).

DSPC analytical methods. Surfactant DSPC methods have been previously described $(19,21)$. Briefly, DSPC from tracheal aspirates was separated by thin layer chromatography after treatment with osmium tetroxide (25). DSPC fatty acids were derivatized as pentafluorobenzyl derivatives (26), extracted with hexane and stored at $-20^{\circ} \mathrm{C}$ until analysis. The enrichment of [U- $\left.{ }^{13} \mathrm{C}-\mathrm{PA}\right]-\mathrm{DSPC}$ from tracheal aspirates was measured by gas chromatography-mass spectrometry (GC-MS, Voyager, Thermoquest, Rodano, Milan, Italy) operating in negative ionization mode. Selective ion monitoring was carried out at $\mathrm{m} / \mathrm{z}, 255,256,257$, and 271 and results expressed as tracer-totracee ratio (ttr) (19).

Surfactant kinetics parameters. Data were analyzed using the two compartment model shown in Fig. 1, assuming that $a$ ) the surfactant is distributed between two compartments (alveoli and lung parenchyma); $b$ ) DSPC is synthesized by lung parenchyma, secreted in the alveoli and recycled before being degraded by alveolar macrophages or in lung tissue; $c$ ) the system is on steady state and is not perturbed by the administration of tracer. In a previous publication, we reported the equations of the model and main assumptions and we demonstrated that the two-compartment model provided the best representation of DSPC kinetics in a similar group of patients with developing BPD (20). Briefly, parameters included DSPC-palmitate alveolar and tissue pool sizes $\left(\mathrm{M}_{1}\right.$ and $\mathrm{M}_{2}$, respectively), de novo synthesis $(\mathrm{P})$, intercompartmental fluxes $\left(\mathrm{F}_{21}, \mathrm{~F}_{12}, \mathrm{~F}_{02}, \mathrm{~F}_{01}\right)$ and recycling $(\mathrm{R})$ were derived from the following equations:

$$
\begin{aligned}
\dot{m}_{1}(t) & =-\left(k_{01}+k_{21}\right) m_{1}(t)+k_{12} m_{2}(t)+u(t) \\
\dot{m}_{2}(t) & =-k_{12} m_{2}(t)+k_{21} m_{1}(t) \\
y(t) & =t r_{1}(t)=\frac{m_{1}(t)}{M_{1}}
\end{aligned}
$$

where $m_{1}$ and $m_{2}(\mathrm{mg})$ were the amount of DSPC-palmitate tracer in compartment 1 and 2 respectively, $k_{21}, k_{12}, k_{01}\left(\mathrm{~h}^{-1}\right)$ were transfer rate parameters, $u$ was the tracer impulsive input into the accessible compartment, $M_{1}(\mathrm{mg})$ was the steady state tracee mass in the accessible compartment.

Tracee model equations were

$$
\begin{aligned}
& M_{1} \cdot(t)=0=-\left(k_{01}+k_{21}\right) M_{1}+k_{12} M_{2} \\
& M_{2}(t)=0=-k_{12} M_{2}+k_{21} M_{1}+P
\end{aligned}
$$

where $M_{2}$ is the steady state tracee mass in the compartment 2 and $P$ was the rate of DSPC-palmitate de novo synthesis. Masses of palmitate residues were multiplied by 1.3025 to obtain DSPC masses. Data were presented as mean \pm $\mathrm{SD}$ and were compared by paired signed rank test (Wilcoxon test). The level of significance was $p<0.05$ Correlations were assessed by parametric (Pearson) and nonparametric (Spearman) methods as appropriate (SPSS12.0).

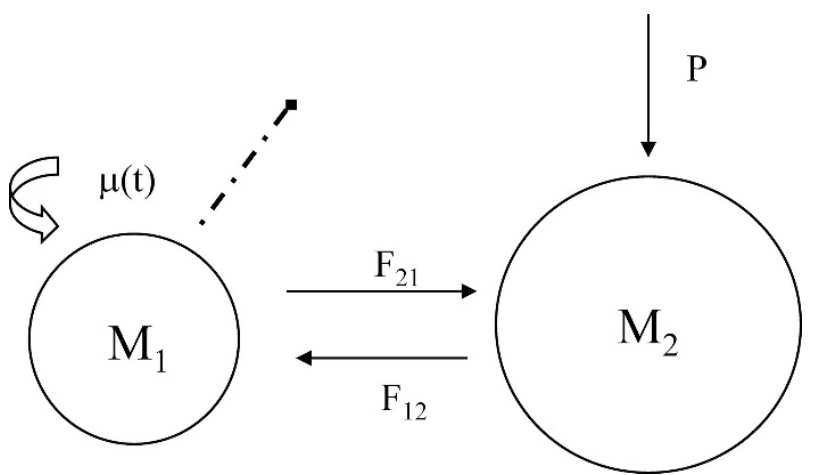

Figure 1. The bi-compartmental model of DSPC kinetics. Compartment $M_{1}$ denotes the accessible alveolar pool, compartment $M_{2}$ the intracellular storage pool, $\mathrm{F}_{21}, \mathrm{~F}_{12}, \mathrm{~F}_{01}$ are intercompartmental fluxes, $\mathrm{P}$ is the rate of DSPC de novo synthesis, $\mathrm{u}$ is the tracer input. The dashed line with bullet denotes the measurements. 


\section{RESULTS}

Seventeen ventilator dependent preterm infants were recruited and completed the first part of the study (Before DEXA).

All patients were on synchronized intermitted mandatory ventilation during the study. Three of the 17 infants were rapidly extubated after the start of DEXA; thus only 14 infants were on ventilator long enough to complete the second phase of the study (After DEXA). Mean birth weight of the 14 infants was $786 \pm 192 \mathrm{~g}$ and gestational age $26 \pm 1 \mathrm{wk}$. DEXA was started at a postnatal age of $31 \pm 3 \mathrm{~d}$ with a mean $\mathrm{FiO}_{2}$ of $0.7 \pm 0.1 \%$. The first dosing of the DPPC tracer was administered at postnatal age $22 \pm 11 \mathrm{~d}$, and the second at $33 \pm 11 \mathrm{~d}$, and after $46 \pm 5 \mathrm{~h}$ from the start of DEXA.

One infant developed lung infection after $4 \mathrm{~d}$ of DEXA (i.e., on day 2 of the second part of the study). Lung infection was diagnosed as worsening the respiratory failure, with temperature instability, increased leukocyte count and serum C-reactive protein level, and positive culture from tracheal secretions. MPO activity from tracheal aspirates increased from $847 \mathrm{mU} / \mathrm{mL}$ ELF before to $6284 \mathrm{mU} / \mathrm{mL}$ ELF during the infection. Data from this patient were excluded from the data analysis. Clinical characteristics of the 13 remaining infants before and after $2 \mathrm{~d}$ of DEXA are reported in Table 1. Eight infants improved their lung condition and survived to discharge, four died before hospital discharge several weeks after the study period, and one was transferred to another hospital after the study was completed. Six controls infants were selected from our surfactant kinetics database for having the same postnatal age as the study infants at the start of the "After DEXA" phase. These infants had the following clinical characteristics: birth weight $852 \pm 129 \mathrm{~g}$, postnatal age $30.1 \pm 10.2 \mathrm{~d}, \mathrm{FiO}_{2} 0.41 \pm 0.12$ and mean airway pressure (MAP) $5.9 \pm 1.3 \mathrm{~cm} \mathrm{H}$ O. Birth weight, postnatal age, and MAP of control infants were not significantly different from those of the "After-DEXA" group. $\mathrm{FiO}_{2}$ was however significantly lower than that of the "After DEXA" group $(p=0.05)$.

Total protein content in tracheal aspirates, before and after DEXA is depicted in Fig. 2, panel A. The mean \pm SD was $8.8 \pm 8.6 \mathrm{mg} / \mathrm{mL}$ ELF before, and $3.1 \pm 2.1 \mathrm{mg} / \mathrm{mL}$ ELF after treatment $(p=0.046)$. MPO was $1822 \pm 1224 \mathrm{mU} / \mathrm{mL}$ ELF before, and $1261 \pm 987 \mathrm{mU} / \mathrm{mL}$ ELF after DEXA ( $p=0.028)$ (Fig. 2 panel $B$ ). We also found a significant correlation between total protein content and MPO activity after DEXA treatment $\left(R^{2}=0.493, p=0.05\right.$, B coefficient 0.01 , constant 1273).

DSPC alveolar pool $\left(M_{1}\right)$ was significantly increased $46 \pm$ $5 \mathrm{~h}$ after DEXA, from $8.2 \pm 7.6$ to $10.6 \pm 11.3 \mathrm{mg} / \mathrm{kg},(p=$ 0.039) (Fig. 3). In the age-matched control group not treated with DEXA, DSPC alveolar pool was $8.6 \pm 5.3 \mathrm{mg} / \mathrm{kg}$, and this was not significantly different from the alveolar pool size of the BPD infants before DEXA ( $p=0.49$ ).

DSPC kinetic parameters before and after DEXA are depicted in Table 2. DSPC synthesis, intercompartmental fluxes, and total DSPC mass tended to be higher already after $46 \pm$ $5 \mathrm{~h}$ from the start of treatment. Changes in DSPC kinetics before and after DEXA were tested for correlation with
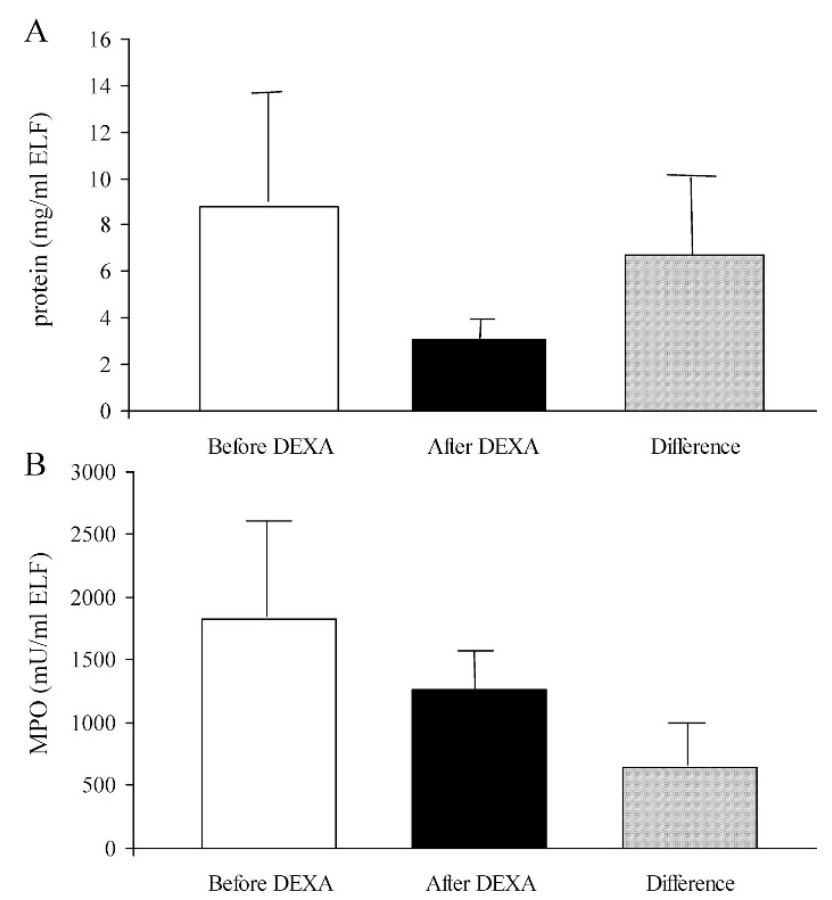

Figure 2. Panel $A$ represents the mean $\pm \mathrm{SD}$ total protein content in tracheal aspirates before and after DEXA treatment. Data are expressed as $\mathrm{mg} / \mathrm{mL}$ ELF. Gray column represents the mean \pm SD reduction in protein content after DEXA. Difference was statistically significant $(p=0.046)$. Panel $B$ represents mean \pm SD myeloperoxidase (MPO) activity in tracheal aspirates before and after DEXA. Data are expressed as mU/mL ELF. Gray column represents the mean \pm SD reduction in MPO after DEXA. Difference resulted statistically significant $(p=0.028)$.

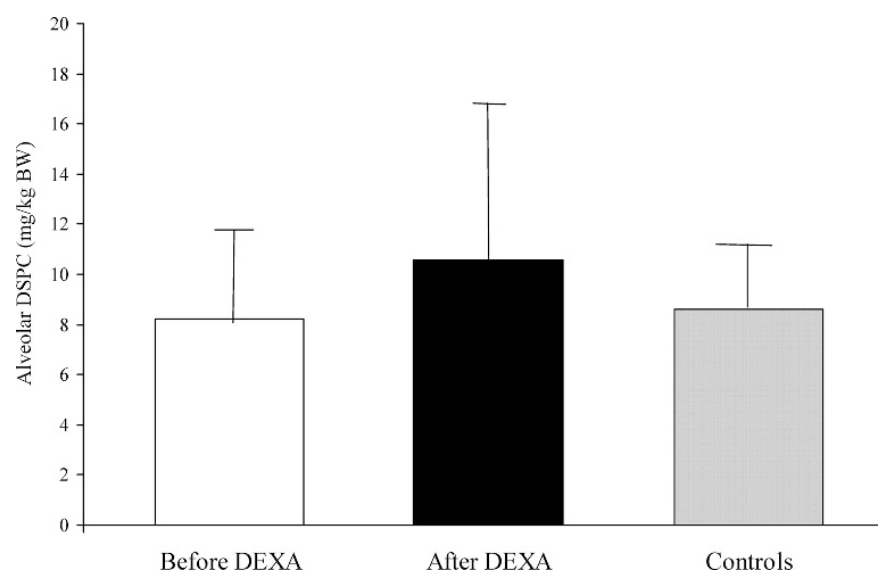

Figure 3. Mean \pm SD alveolar DSPC pools in the 13 study infants before and after DEXA (white and gray columns) and in the six controls (gray column). Data are expressed as $\mathrm{mg} / \mathrm{kg}$ body weight. Significant difference was found between DSPC alveolar pool before and after DEXA $(p=0.039)$.

changes in ventilatory parameters, total protein and MPO activity. Significant correlations were found between DSPC tissue $\left(M_{2}\right)$ changes and MAP variations $(\rho=0.593, p=$ $0.05)$. No correlation was found between DSPC kinetic parameters and total proteins and MPO content in tracheal aspirates.

\section{DISCUSSION}

In the present study, we used a method developed by our group based on the use of the safe (nonradioactive) stable 
Table 2. Bicompartmental model parameters of DSPC kinetics

\begin{tabular}{lccc}
\hline DSPC parameters & $\begin{array}{c}\text { Before DEXA } \\
(\mathrm{n}=13)\end{array}$ & $\begin{array}{c}\text { After DEXA } \\
(\mathrm{n}=13)\end{array}$ & $\begin{array}{c}\mathrm{p}^{*} \text { before/after } \\
\text { DEXA }\end{array}$ \\
\hline $\mathrm{M}_{1}(\mathrm{mg} / \mathrm{kg})$ & $8.2 \pm 7.6$ & $10.6 \pm 11.3$ & 0.039 \\
$\mathrm{M}_{2}(\mathrm{mg} / \mathrm{kg})$ & $32.1 \pm 14.7$ & $36.9 \pm 27.4$ & 0.507 \\
$\mathrm{M}_{\text {tot }}(\mathrm{mg} / \mathrm{kg})$ & $40.3 \pm 17.9$ & $47.5 \pm 36.1$ & 0.311 \\
$\mathrm{P}(\mathrm{mg} / \mathrm{day} / \mathrm{kg})$ & $11.0 \pm 5.2$ & $15.0 \pm 12.3$ & 0.311 \\
$\mathrm{~F}_{21}(\mathrm{mg} / \mathrm{day} / \mathrm{kg})$ & $4.6 \pm 3.8$ & $7.3 \pm 9.2$ & 0.345 \\
$\mathrm{~F}_{12}(\mathrm{mg} / \mathrm{day} / \mathrm{kg})$ & $15.2 \pm 7.9$ & $22.1 \pm 21.1$ & 0.221 \\
$\mathrm{R}(\%)$ & $24.5 \pm 13.1$ & $29.6 \pm 14.3$ & 0.279 \\
\hline
\end{tabular}

Data are expressed as mean \pm SD.

* $p$ between before and after DEXA (Wilkoxon Sign Rank test).

DEXA, dexamethasone; $M_{1}(\mathrm{mg})$, DSPC mass in the alveolar compartment; $M_{2}$ (mg), DSPC mass in the tissue compartment; $\mathrm{M}_{\text {tot }}(\mathrm{mg} / \mathrm{kg})$ DSPC total mass in the system; $P(\mathrm{mg} / \mathrm{d} / \mathrm{kg})$, rate of DSPC de novo synthesis; $\mathrm{F}_{21}, \mathrm{~F}_{12}$, $\mathrm{F}_{01}(\mathrm{mg} / \mathrm{d})$, intercompartmental DSPC fluxes; $R(\%)$, recycling of DSPC, equal to the ratio between $\mathrm{F}_{21}$ and $\mathrm{F}_{21}+\mathrm{F}_{01}$ expressed as $\%$.

isotopes to trace the changes of pulmonary surfactant DSPC induced by DEXA treatment. Patients were extremely low gestational age newborns with life-threatening respiratory failure and at a very high risk of developing BPD. We found, already after $46 \pm 5 \mathrm{~h}$ from the start of DEXA, a significant increase in alveolar DSPC and a trend toward higher DSPC synthesis.

This represents novel information. We also showed a reduced total protein content and a reduced MPO activity in tracheal aspirates, confirming previous findings in preterm infants with chronic lung disease $(12-14,16,18)$.

Clinical considerations. Albeit, DEXA treatment is nowadays limited to a small number of preterm infants with life threatening respiratory failure, and its often dramatic effect in improving respiratory status and facilitating extubation is widely accepted $(8,27)$. Thus, preterm infants with very severe respiratory failure are still being treated with corticosteroids, despite the awareness of the negative effects on neurodevelopment $(8,27,28)$. The mechanisms for the improvement in lung function are not fully elucidated, and possibly include a down-regulation of lung inflammation (29) and a reduction of lung water $(30,31)$. Scanty information exists on the role of DEXA on surfactant metabolism in general and more so in human infants.

We studied infants with very severe respiratory failure and high likelihood of developing BPD, who received DEXA after 3 wk of age. Dosing and time of administration were based on local guidelines at the time of the study. DEXA treatment led to extubation in $71 \%$ of the patients.

Effect of steroids on lung inflammation. We found a significant reduction of MPO activity after DEXA as a sign of decreased neutrophil sequestration in the lungs (32). Glucocorticoids are widely used for their capacity to suppress inflammation in chronic inflammatory diseases (7). The use of DEXA in BPD has been shown to suppress the expression of nuclear factor-kappa B in leukocytes and mononuclear cells obtained from tracheobronchial lavage fluid of preterm infants with chronic lung disease $(13,14)$. Neutrophil infiltration has been shown to be important in the development of inflammation, edema and microvascular leakage in a variety of animal models and in humans (33-36). Thus, the decreased MPO activity after DEXA suggests a direct anti-inflammatory action occurring rather early after treatment start. We also found that total proteins were significantly reduced after DEXA. Interestingly, total protein content and MPO activity after DEXA were significantly correlated, suggesting that neutrophil infiltration in the lungs and alveolar capillary protein leak are likely to be two interconnected phenomena. MPO values decreased progressively after DEXA, and the changes became significant after $2 \mathrm{~d}$, suggesting that the anti-inflammatory effect of DEXA in preterm lungs is quite fast. Other mechanisms of improved lung function include a maturation of the alveolar-capillary barrier and increased lung water reabsorption $(7,37)$. These mechanisms will be hard to demonstrate in humans with the available technology.

Effect of DEXA on surfactant. We found a marked effect of DEXA in increasing alveolar surfactant. Extensive literature exists on the role of corticosteroids on lung and surfactant maturation in preterm animals and in infants. Information on lung injury and lung inflammation is limited. In animal models of chronic lung disease and in preterm infants with BPD, profound alterations of surfactant phospholipids and proteins have been described. Seidner et al. reported that baboons with chronic lung disease had a higher DSPC synthesis and lower DSPC secretion compared with controls, leading to a low alveolar DSPC pool size (12\% of the total lung pool) (38). At the time of killing, lung type II cells appeared hyperplastic and rich of lamellar bodies, similar to the type II cells observed in human BPD (38). Ballard et al. showed that 125-d-old baboons with chronic lung diseases had dysfunctional surfactant at $14 \mathrm{~d}$ and decreased amounts of SP-B (39).

We previously reported that alveolar DSPC was $8.9 \pm 5.9$ $\mathrm{mg} / \mathrm{kg}$ body weight in preterm infants with developing BPD and not treated with steroids, and $14.4 \pm 8.2 \mathrm{mg} / \mathrm{kg}$ body weight in gestational age- and birth weight-matched controls (20). In this study, the six control infants had $8.6 \pm 5.3 \mathrm{mg} / \mathrm{kg}$, and in the treated patients, it increased from $8.2 \pm 7.6$ to $10.6 \pm 11.3 \mathrm{mg} / \mathrm{kg}$ already at $46 \pm 5 \mathrm{~h}$ from DEXA $(p=$ $0.039)$. Performing the "After DEXA study" $2 \mathrm{~d}$ after treatment start represents a compromise between waiting long enough to detect significant changes in DSPC kinetics, and the risk of not being able to complete the study because of "early" extubations. Had we chosen to study the patients earlier, we would likely have found much smaller changes in surfactant kinetics. This is not only because of the time required for DEXA to show clinical effects but, perhaps more importantly, because of the slow turnover of pulmonary surfactant. We interpret a mean increase of $30 \%$ of the alveolar pool and of $20 \%$ of the tissue pool $2 \mathrm{~d}$ only after DEXA as a clinically significant change. A more sizable effect could have likely been found after 3 or $4 \mathrm{~d}$, but at risk of losing patients because of "early extubation." Changes in DSPC tissue pool did not reach statistical significance probably because of the limited number of infants. However, the increment of total and tissue DSPC pools was significantly associated with a reduction in MAP. DSPC synthesis and rate of secretion from tissue to alveolar pool $\left(\mathrm{F}_{12}\right)$ were highly variable among study infants, but they all tended to be higher after DEXA. Increased DSPC synthesis was shown by Bunt et al. in preterm infants with 
RDS after prenatal steroids $(40,41)$. In this study, we found that DSPC synthesis $(\mathrm{P})$ was increased by one-third and DSPC secretion $\left(\mathrm{F}_{21}\right)$ almost doubled $46 \pm 5 \mathrm{~h}$ after DEXA. Nevertheless, after $46 \pm 5 \mathrm{~h}$, six infants had alveolar DSPC values of less than $3.5 \mathrm{mg} / \mathrm{kg}$, which is about $25 \%$ of what we reported in preterm infants with minimal lung disease (20). This finding warrants further investigations. Of note, four of these six infants subsequently died of irreversible respiratory failure.

BPD is multifactorial and the degree of inflammation and injury, the response to pharmacological treatment and the surfactant alterations vary greatly among patients. Genetic polymorphism may partially explain this variability $(42,43)$.

In conclusion, in infants with life-threatening respiratory failure and developing BPD, DEXA treatment decreased oxygen dependency, facilitated extubation, decreased inflammatory markers and improved the surfactant status.

Acknowledgments. We gratefully acknowledge the essential contribution of the nurses of Neonatal Intensive Care Unit who enthusiastically contributed to the sample collection.

\section{REFERENCES}

1. Coalson JJ, Winter V, deLemos RA 1995 Decreased alveolarization in baboon survivors with bronchopulmonary dysplasia. Am J Respir Crit Care Med 152:640-646

2. Jobe AJ 1999 The new BPD: an arrest of lung development. Pediatr Res 46:641-643

3. Kazzi SN, Schurch S, McLaughlin KL, Romero R, Janisse J 2000 Surfactant phospholipids and surface activity among preterm infants with respiratory distress syndrome who develop bronchopulmonary dysplasia. Acta Paediatr 89:1218-1225

4. Obladen M 1988 Alterations in surfactant composition. In: Merritt TA, Northway WH, Boynton BR (eds) Bronchopulmonary Dysplasia. Blackwell Scientific, Boston, pp 131-141

5. Hallman M, Merritt TA, Akino T, Bry K 1991 Surfactant protein A, phosphatidylcholine, and surfactant inhibitors in epithelial lining fluid. Correlation with surface activity, severity of respiratory distress syndrome, and outcome in small premature infants. Am Rev Respir Dis 144:1376-1384

6. Ballard PL, Merrill JD, Godinez RI, Godinez MH, Truog WE, Ballard RA 2003 Surfactant protein profile of pulmonary surfactant in premature infants. Am J Respir Crit Care Med 168:1123-1128

7. Barnes PJ 1998 Anti-inflammatory actions of glucocorticoids: molecular mechanisms. Clin Sci (Lond) 94:557-572

8. Halliday HL, Ehrenkranz RA, Doyle LW 2003 Delayed ( $>3$ weeks) postnatal corticosteroids for chronic lung disease in preterm infants. Cochrane Database Syst Rev CD001145

9. Committee on Fetus and Newborn 2002 Postnatal corticosteroids to treat or prevent chronic lung disease in preterm infants. Pediatrics 109:330-338

10. Walsh MC, Yao Q, Horbar JD, Carpenter JH, Lee SK, Ohlsson A 2006 Changes in the use of postnatal steroids for bronchopulmonary dysplasia in 3 large neonatal networks. Pediatrics 118:e1328-e1355

11. Ikegami M, Berry D, elKady T, Pettenazzo A, Seidner S, Jobe A 1987 Corticosteroids and surfactant change lung function and protein leaks in the lungs of ventilated premature rabbits. J Clin Invest 79:1371-1378

12. Watts CL, Bruce MC 1992 Effect of dexamethasone therapy on fibronectin and albumin levels in lung secretions of infants with bronchopulmonary dysplasia. J Pediatr 121:597-607

13. Groneck P, Reuss D, Gotze-Speer B, Speer CP 1993 Effects of dexamethasone on chemotactic activity and inflammatory mediators in tracheobronchial aspirates of preterm infants at risk for chronic lung disease. J Pediatr 122:938-944

14. Vento G, Matassa PG, Zecca E, Tortorolo L, Martelli M, De Carolis MP, Maggio L, Zini G, D'Onofrio G, Valentini S, Romagnoli C 2004 Effect of dexamethasone on tracheobronchial aspirate fluid cytology and pulmonary mechanics in preterm infants. Pharmacology 71:113-119

15. Holm BA, Wang Z, Notter RH 1999 Multiple mechanisms of lung surfactant inhibition. Pediatr Res 46:85-93

16. Ballabh P, Kumari J, Krauss AN, Shin JJ, Jain A, Auld PA, Lesser ML, CunninghamRundles S 2003 Soluble E-selectin, soluble L-selectin and soluble ICAM-1 in bronchopulmonary dysplasia, and changes with dexamethasone. Pediatrics 111:461-468

17. Rooney SA 1998 Regulation of surfactant phospholipid biosynthesis. In: Rooney SA (ed) Lung Surfactant: Cellular and Molecular Processing. RG Landers, Austin, TX, pp 29-45

18. Kari MA, Raivio KO, Venge P, Hallman M 1994 Dexamethasone treatment of infants at risk for chronic lung disease: surfactant components and inflammatory parameters in airway specimens. Pediatr Res 36:387-393
19. Torresin M, Zimmermann LJ, Cogo PE, Cavicchioli P, Badon T, Giordano G, Zacchello F, Sauer PJ, Carnielli VP 2000 Exogenous surfactant kinetics in infant respiratory distress syndrome: a novel method with stable isotopes. Am J Respir Crit Care Med 161:1584-1589

20. Cogo PE, Toffolo GM, Gucciardi A, Benetazzo A, Cobelli C, Carnielli VP 2005 Surfactant disaturated phosphatidylcholine kinetics in infants with bronchopulmonary dysplasia measured with stable isotopes and a two-compartment model. J Appl Physiol 99:323-329

21. Cogo PE, Zimmermann LJ, Pesavento R, Sacchetto E, Burighel A, Rosso F, Badon T, Verlato G, Carnielli VP 2003 Surfactant kinetics in preterm infants on mechanical ventilation who did and did not develop bronchopulmonary dysplasia. Crit Care Med 31:1532-1538

22. Lowry OH, Rosebrough NJ, Farr AL, Randall RJ 1951 Protein measurement with the Folin phenol reagent. J Biol Chem 193:265-275

23. Dargaville PA, South M, Vervaart P, McDougall PN 1999 Validity of markers of dilution in small volume lung lavage. Am J Respir Crit Care Med 160:778-784

24. Vinardi S, Pierro A, Parkinson EJ, Vejchapipat P, Stefanutti G, Spitz L, Eaton S 2003 Hypothermia throughout intestinal ischaemia-reperfusion injury attenuates lung neutrophil infiltration. J Pediatr Surg 38:88-91

25. Mason RJ, Nellenbogen J, Clements JA 1976 Isolation of disaturated phosphatidylcholine with osmium tetroxide. J Lipid Res 17:281-284

26. Christie WW 1989 The analysis of fatty acids. In: Christie WW (ed) Gas Chromatography and Lipids. A Practical Guide. The oil press, Ayr, Scotland, pp 64-84

27. Anttila E, Peltoniemi O, Haumont D, Herting E, ter Horst H, Heinonen K, Kero P, Nykanen P, Oetomo SB, Hallman M 2005 Early neonatal dexamethasone treatment for prevention of bronchopulmonary dysplasia. Randomised trial and meta-analysis evaluating the duration of dexamethasone therapy. Eur J Pediatr 164:472-481

28. Doyle LW, Davis PG, Morley CJ, McPhee A, Carlin JB 2006 Low-dose dexamethasone facilitates extubation among chronically ventilator-dependent infants: a multicenter, international, randomized, controlled trial. Pediatrics 117:75-83

29. Aghai ZH, Kumar S, Farhath S, Kumar MA, Saslow J, Nakhla T, Eydelman R, Strande L, Stahl G, Hewitt C, Nesin M, Rahman I 2006 Dexamethasone suppresses expression of Nuclear Factor-kappaB in the cells of tracheobronchial lavage fluid in premature neonates with respiratory distress. Pediatr Res 59:811-815

30. Bland RD, Albertine KH, Carlton DP, Kullama L, Davis P, Cho SC, Kim BI, Dahl M, Tabatabaei N 2000 Chronic lung injury in preterm lambs: abnormalities of the pulmonary circulation and lung fluid balance. Pediatr Res 48:64-74

31. Bolt RJ, van Weissenbruch MM, Lafeber HN, Delemarre-van de Waal HA 2001 Glucocorticoids and lung development in the fetus and preterm infant. Pediatr Pulmonol 32:76-91

32. Buss IH, Senthilmohan R, Darlow BA, Mogridge N, Kettle AJ, Winterbourn CC 2003 3-Chlorotyrosine as a marker of protein damage by myeloperoxidase in tracheal aspirates from preterm infants: association with adverse respiratory outcome. Pediatr Res 53:455-462

33. Steinberg KP, Milberg JA, Martin TR, Maunder RJ, Cockrill BA, Hudson LD 1994 Evolution of bronchoalveolar cell populations in the adult respiratory distress syndrome. Am J Respir Crit Care Med 150:113-122

34. Martin TR, Pistorese BP, Hudson LD, Maunder RJ 1991 The function of lung and blood neutrophils in patients with the adult respiratory distress syndrome. Implications for the pathogenesis of lung infections. Am Rev Respir Dis 144:254-262

35. Pugin J, Verghese G, Widmer MC, Matthay MA 1999 The alveolar space is the site of intense inflammatory and profibrotic reactions in the early phase of acute respiratory distress syndrome. Crit Care Med 27:304-312

36. Ishizaka A, Watanabe M, Yamashita T, Ogawa Y, Koh H, Hasegawa N, Nakamura H, Asano K, Yamaguchi K, Kotani M, Kotani T, Morisaki H, Takeda J, Kobayashi K, Ogawa S 2001 New bronchoscopic microsample probe to measure the biochemical constituents in epithelial lining fluid of patients with acute respiratory distress syndrome. Crit Care Med 29:896-898

37. Ramminger SJ, Richard K, Inglis SK, Land SC, Olver RE, Wilson SM 2004 A regulated apical $\mathrm{Na}(+)$ conductance in dexamethasone-treated $\mathrm{H} 441$ airway epithelial cells. Am J Physiol Lung Cell Mol Physiol 287:L411-L419

38. Seidner SR, Jobe AH, Coalson JJ, Ikegami M 1998 Abnormal surfactant metabolism and function in preterm ventilated baboons. Am J Respir Crit Care Med 158:19821989

39. Ballard PL, Gonzales LW, Godinez RI, Godinez MH, Savani RC, McCurnin DC, Gibson LL, Yoder BA, Kerecman JD, Grubb PH, Shaul PW 2006 Surfactant composition and function in a primate model of infants with chronic lung disease: effect of inhaled nitric oxide. Pediatr Res 59:157-163

40. Bunt JE, Carnielli VP, Janssen DJ, Wattimena JL, Hop WC, Sauer PJ, Zimmermann LJ 2000 Treatment with exogenous surfactant stimulates endogenous surfactant synthesis in premature infants with respiratory distress syndrome. Crit Care Med 28:3383-3388

41. Bunt JE, Carnielli VP, Darcos Wattimena JL, Hop WC, Sauer PJ, Zimmermann LJ 2000 The effect in premature infants of prenatal corticosteroids on endogenous surfactant synthesis as measured with stable isotopes. Am J Respir Crit Care Med 162:844-849

42. Floros J, Thomas NJ, Liu W, Papagaroufalis C, Xanthou M, Pereira S, Fan R, Guo X, Diangelo S, Pavlovic J 2006 Family-based association tests suggest linkage between surfactant protein-B (SP-B) (and flanking region) and respiratory distress syndrome (RDS): SP-B haplotypes and alleles from SP-B-linked loci are risk factors for RDS. Pediatr Res 59:616-621

43. Marttila R, Haataja R, Guttentag SH, Hallman M 2003 Surfactant protein A and B genetic variants in respiratory distress syndrome in singletons and twins. Am J Respir Crit Care Med 168:1216-1222 